\title{
PEMANFAATAN ECENG GONDOK SEBAGAI ADSORBEN Pb ASETAT
}

\author{
OTONG NURHILAL*, SRI SURYANINGSIH, FERRY FAIZAL, RENALDY SHARIN \\ LESMANA \\ Departemen Fisika Fakultas MIPA Universitas Padjadjaran, \\ Jl. Raya Bandung-Sumedang Km 21,Jatinangor 45363 \\ *email : otong.nurhilal@phys.unpad.ac.id
}

\begin{abstract}
Abstrak. Eceng gondok (EG) merupakan jenis tanaman yang tumbuh dengan cepat dan dianggap sebagai gulma. EG mengandung sekitar $70 \%$ lignoselulosa yang bisa dimanfaatkan untuk bahan arang aktif. Pada penelitian ini EG telah dibuat sebagai arang aktif melalui proses karbonisasi pada temperatur $400^{\circ} \mathrm{C}$ dan aktivasi dengan aktivator $\mathrm{ZnCl}_{2} 30 \%$. Karakterisasi yang dilakukan yaitu uji proksimasi dan uji luas permukaan dengan metode BET. Arang aktif yang dihasilkan digunakan sebagai adsorben larutan $\mathrm{Pb}$ asetat buatan. Dari hasil pengujian proksimasi diperoleh kadar karbon terikat 37,79\%. Morfologi arang aktif setelah diaktivasi memiliki volume pori sebesar $0,055 \mathrm{cc} / \mathrm{g}$ dan luas permukaan spesifik sebesar 104,32 $\mathrm{m}^{2} / \mathrm{g}$. Pengukuran adsorben limbah $\mathrm{Pb}$ asetat dilakukan dengan mencampurkan arang aktif ke dalam larutan $\mathrm{Pb}$ asetat dengan variasi konsentrasi 4 ppm, 8 ppm, dan 12 ppm. Hasil yang diperoleh secara keseluruhan konsentrasi larutan $\mathrm{Pb}$ asetat mengalami pengurangan setelah dicampurkan dengan arang aktif. Pada arang aktif 0,5 gram penurunan terbesar terjadi pada konsentrasi limbah $\mathrm{Pb}$ asetat 12 ppm dengan waktu kontak selama 20 menit, konsentrasi larutan $\mathrm{Pb}$ asetat berkurang menjadi $0,59 \mathrm{ppm}$ dengan persentase larutan $\mathrm{Pb}$ asetat yang terserap sebesar $23,75 \%$. Sementara pada arang aktif 0,8 gram penurunan terbesar terjadi pada konsentrasi limbah $\mathrm{Pb}$ asetat 12 ppm dengan waktu kontak selama 30 menit, konsentrasi larutan $\mathrm{Pb}$ asetat berkurang menjadi $0,73 \mathrm{ppm}$ dengan persentase larutan $\mathrm{Pb}$ asetat yang terserap sebesar $27,69 \%$.
\end{abstract}

Kata kunci: arang aktif, adsorpsi, degradasi, eceng gondok, $\mathrm{Pb}$ asetat

Abstract. Water hyacinth is a type of plant that grows quickly and is considered a weed. WH contains about $70 \%$ lignocellulose which can be used for active charcoal. In this study WH has been made as activated charcoal through carbonization at a temperature of $400^{\circ} \mathrm{C}$ and activation with a $30 \% \mathrm{ZnCl}_{2}$ activator. Characterization carried out is the estimation test and surface area test using the BET method. The activated charcoal produced is used as an adsorbent for an artificial $\mathrm{Pb}$ acetate solution. From the results of proximate testing obtained fixed carbon content of $37.79 \%$. Morphology of activated charcoal after activation has a pore volume total of $0.055 \mathrm{cc} / \mathrm{g}$ and a specific surface area of $104.32 \mathrm{~m}^{2} / \mathrm{g}$. The measurement of $\mathrm{Pb}$ acetate waste adsorbent is done by mixing activated charcoal into a solution of $\mathrm{Pb}$ acetate with varying concentrations of $4 \mathrm{ppm}, 8$ ppm and $12 \mathrm{ppm}$. The results obtained as a whole concentration of $\mathrm{Pb}$ acetate solution has decreased after mixed with activated charcoal. At 0.5 grams of activated charcoal the greatest decrease occurred in the concentration of $\mathrm{Pb}$ acetate waste $12 \mathrm{ppm}$ with a contact time for 20 minutes, the concentration of $\mathrm{Pb}$ acetate solution was reduced to $0.59 \mathrm{ppm}$ with the percentage of $\mathrm{Pb}$ acetate solution absorbed at $23.75 \%$. While in activated charcoal 0.8 gram the biggest decrease occurred in the concentration of $\mathrm{Pb}$ acetate waste $12 \mathrm{ppm}$ with contact time for 30 minutes, the concentration of $\mathrm{Pb}$ acetate solution was reduced to $0.73 \mathrm{ppm}$ with the percentage of $\mathrm{Pb}$ acetate solution absorbed at $27.69 \%$.

Keywords: activated charcoal, adsorption, degradation, water hyacinth, $\mathrm{Pb}$ acetate

JIIF (Jurnal Ilmu dan Inovasi Fisika), ISSN: 2549-0516 


\section{Pendahuluan}

Eceng gondok merupakan tumbuhan air yang memiliki pertumbuhan sangat cepat sehingga tumbuhan ini dianggap sebagai gulma yang merusak lingkungan perairan [1]. EG dapat menyebar di area yang luas dan menutupi permukaan air, dapat mengurangi cahaya yang masuk ke dalam air yang mengakibatkan berkurangnya kandungan oksigen terlarut dalam air. EG yang mati dan mengendap di dasar air, meningkatkan persaingan dengan tumbuhan lain [2].

Eceng gondok memiliki kandungan selulosa dan hemiselulosa yang tinggi, sebesar selulosa $60 \%$, hemiselulosa $8 \%$, lignin $17 \%$ dan sisanya adalah zat-zat yang lainnya [1]. Pertumbuhan eceng gondok dapat mencapai $100 \%$ hanya memerlukan waktu 4 hari [3]. Melihat pertumbuhan yang sangat cepat ini, akan menjamin ketersediaan eceng gondok sebagai bahan baku arang aktif.

Kandungan lignoselulosa yang tinggi dari EG bisa dimanfaatkan untuk pembuatan arang aktif. Arang aktif yang dihasilkan dapat digunakan sebagai adsorben, katalis, kapasitor elektrokimia, semikonduktor, baterai dan sebagainya. Arang aktif berbentuk kristal mikro dan arang nanografit yang pori-porinya mampu mengabsorpsi gas dan uap serta zat- zat yang terlarut atau terdispensasi dalam cairan melalui aktivasi [1]. Proses pembuatan arang aktif dipengaruhi oleh temperatur kabonisasi dan aktivasi. Pada penelitian ini telah dibuat arang aktif dari EG dengan temperatur karbonisasi $400^{\circ} \mathrm{C}$ yang diaktivasi dengan $\mathrm{ZnCl}_{2}$. Arang aktif yang dihasilkan diiuji daya serapnya pada limbah $\mathrm{Pb}$ asetat. Timbal atau $\mathrm{Pb}$ adalah logam yang bersifat neurotoxin (racun pada sistem saraf) dan bersifat akumulatif karena sifatnya yang stabil serta memiliki waktu paruh yang lama [4]. Timbal sangat berbahaya bagi lingkungan, jika Timbal yang terbuang ke lingkungan telah melampaui nilai ambang yang ditentukan $(0,03 \mathrm{mg} / \mathrm{l}$ untuk perairan tempat hidup biota laut dan air tawar serta $0,02 \mathrm{mg} / \mathrm{l}$ untuk air konsumsi) [4]. Pemaparan yang tinggi dapat menyebabkan kerusakan otak dan kematian. Maka untuk mencegah pencemaran yang diakibatkan oleh Timbal dapat diatasi dengan menggunakan arang aktif sebagai adsorben.

\section{Metode Penelitian}

EG dikeringkan dibawah sinar matahari selama 2 hari, dikarbonisasi pada temperature $400{ }^{\circ} \mathrm{C}$. Penghalusan pada 325 mesh dan pengeringan pada temperaur $100{ }^{\circ} \mathrm{C}$ selama 2 jam. Aktivasi dengan $\mathrm{ZnCl}_{2} 30 \%$ selama 24 jam, kemudian dicuci dengan aquades beberapa kali untuk mencapai $\mathrm{pH} 7$ dan pengeringan pada temperature $105{ }^{\circ} \mathrm{C}$ selama 12 jam. Uji karakteristik meliputi uji proksimasi untuk mengetahui kadar karbon terikat dan uji luas permukaan dengan metode BrunauerEmmett-Teller (BET). Daya serap arang aktif diuji pada limbah $\mathrm{Pb}$ asetat dan diukur adsorbansinya menggunakan spektrometer UV-Vis. Pembuatan larutan $\mathrm{Pb}$ asetat 4 ppm digunakan $0,08 \mathrm{mg} \mathrm{Pb}$ asetat yang dilarutkan dengan aquades sampai massa larutan yang terukur sebesar 0,02 L. Begitu pula untuk larutan $\mathrm{Pb}$ asetat $8 \mathrm{ppm}$ dan $12 \mathrm{ppm}$ dapat dihitung menggunakan persamaan diatas. Arang aktif sebesar 0,5 gram dan 0,8 gram lalu dimasukkan ke dalam gelas kimia. Kemudian, ditambahkan larutan $\mathrm{Pb}$ asetat sebanyak $20 \mathrm{ml}$ dengan variasi kadar $\mathrm{Pb} 4$ ppm, 8 ppm, dan 12 ppm. Selanjutnya, diaduk dengan pengaduk magnetik (magnetic stirrer) dengan variasi waktu selama 10 menit, 20 menit, dan 30 menit. Kemudian larutan disaring menggunakan kertas saring untuk memisahkan antara filtrat dan residunya. Limbah atau filtrat diambil sekitar $2 \mathrm{ml}$ sebagai sampel. Filtrasi hasil saringan diukur 
konsentrasi $\mathrm{Pb}$ yang tersisa dengan menggunakan Spektrometer UV-Vis. Panjang gelombang yang digunakan untuk analisa kandungan $\mathrm{Pb}$ adalah $200-800 \mathrm{~nm}$.

\section{Hasil dan Pembahasan}

Dari hasil uji proksimasi arang diperoleh kadar air 6,64 \%, kadar abu 37,09 \%, kadar zat terbang 18,48 \% dan kadar karbon terikat 37,79 \%. Dari hasil uji BET arang aktif diperoleh luas permukaan spesifik $104,32 \mathrm{~m}^{2} / \mathrm{g}$ dan total volume pori 0,055 cc/g. Gambar 1 memperlihatkan proses adsorpsi dan desorpsi $\mathrm{N}_{2}$ pada temperatur $77 \mathrm{~K}$.

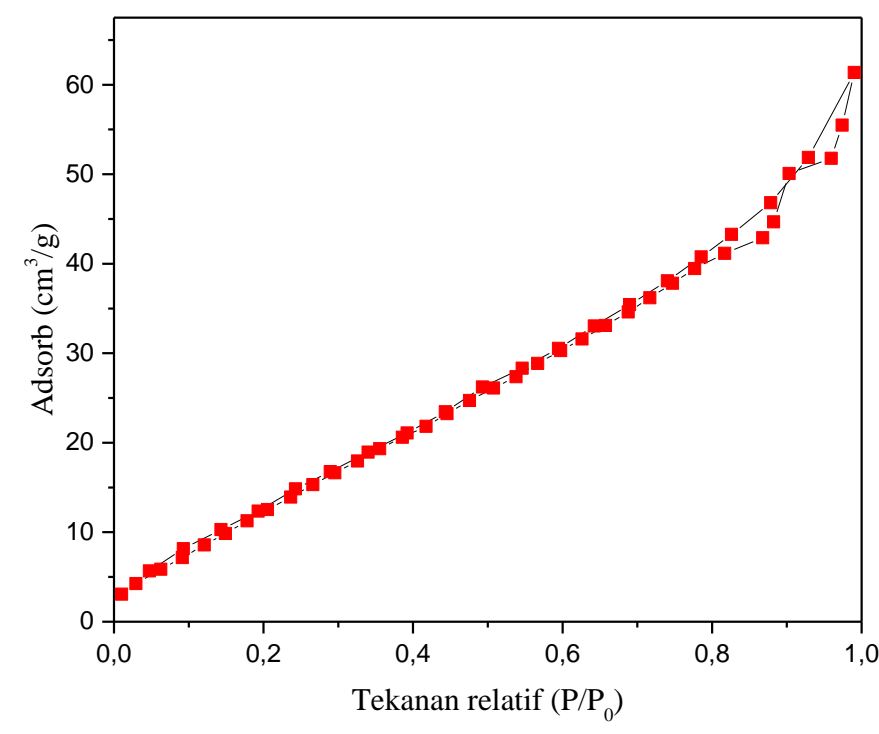

Gambar 1. Kurva adsorpsi dan desorpsi N2 arang aktif EG

Nilai luas permukaan spesifik arang aktif EG masih sangat rendah. Hal ini disebabkan proses aktivasi belum mampu membuka pori dari kotoran-kotorannya karena tidak dilakukan kalsinasi. Adapun hasil karakterisasi absorbansi sampel arang aktif terhadap $\mathrm{Pb}$ dengan waktu kontak 10, 20 dan 30 menit di perlihatkan pada Gambar 2 dan 3.

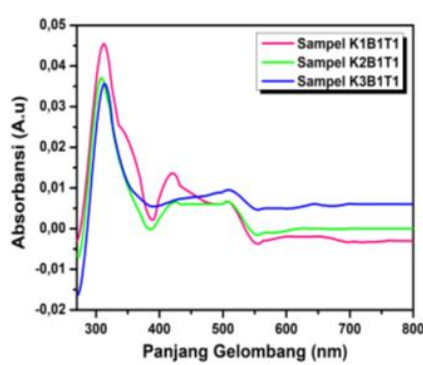

(a)

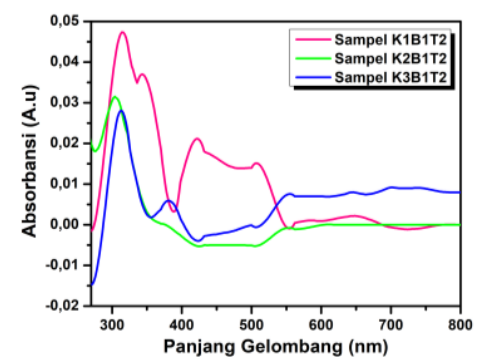

(b)

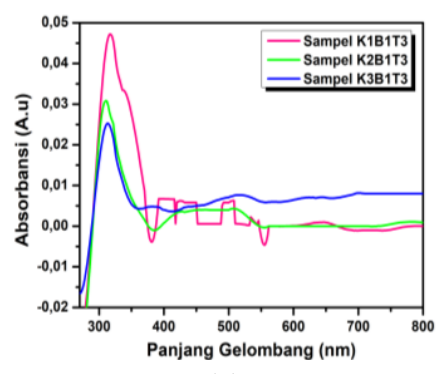

(c)

Gambar 2. Kurva absorbansi larutan $\mathrm{Pb}$ asetat dengan massa arang aktif 0,5 gram, (a) pada waktu 10 menit (b) pada waktu 20 menit (c) pada waktu 30 menit 


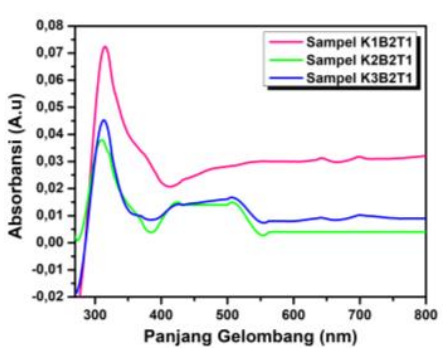

(a)

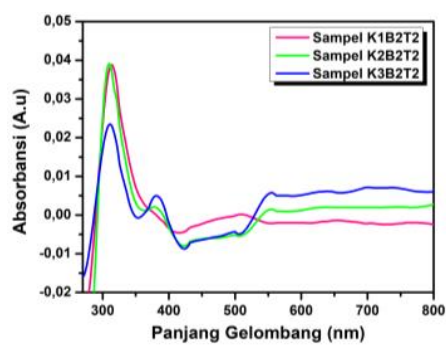

(b)

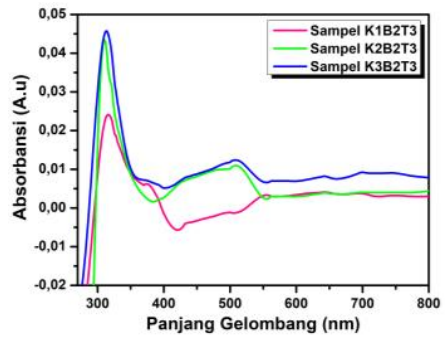

(c)

Gambar 3. Kurva absorbansi larutan $\mathrm{Pb}$ asetat dengan massa arang aktif 0,8 gram, (a) pada waktu 10 menit (b) pada waktu 20 menit (c) pada waktu 30 menit

Nilai panjang gelombang untuk puncak absorpsi (absorbansi maksimum) di cantumkan pada Tabel 1 untuk massa arang aktif 0,5 dan 0,8 gram.

Tabel 1. Nilai absorbansi maksimum larutan $\mathrm{Pb}$ asetat setelah dicampurkan dengan arang aktif EG sebesar 0,5 dan 0,8 gram

\begin{tabular}{cccccc}
\hline $\begin{array}{c}\text { Waktu } \\
\text { (menit) }\end{array}$ & $\begin{array}{c}\text { Konsentrasi } \\
(\mathrm{ppm})\end{array}$ & \multicolumn{2}{c}{ Absorbansi (A.u) } & \multicolumn{2}{c}{ Panjang Gelombang (nm) } \\
\hline \multirow{2}{*}{10} & 4 & 0,0006 & 0,029 & 517,1 & 514,7 \\
& 8 & 0,0041 & 0,015 & 514,4 & 508,7 \\
& 12 & 0,0077 & 0,017 & 518,1 & 510,6 \\
20 & 4 & 0,0012 & 0,0003 & 553,9 & 508,6 \\
& 8 & 0,0072 & 0,0014 & 553,9 & 554,6 \\
& 12 & 0,0079 & 0,0057 & 553,7 & 554,6 \\
30 & 4 & 0,0048 & 0,0021 & 516,2 & 535,9 \\
& 8 & 0,0064 & 0,0110 & 508,7 & 511,6 \\
& 12 & 0,0094 & 0,0121 & 511,6 & 513,5 \\
\hline
\end{tabular}

Tabel 1 menunjukkan hasil pengukuran spektrometer UV-Vis yang digunakan untuk menganalisis konsentrasi larutan $\mathrm{Pb}$ asetat sebelum dan setelah dilakukan pengujian dengan arang aktif eceng gondok. Dari Tabel 1 puncak absorpsi unutk massa aranag aktif 0,5 gram terjadi pada panjang gelombang disekitar 508,7-553,9 nm dengan nilai absorbansi disekitar 0,0006-0,0094 A.u. Untuk massa aranag aktif 0,8 gram puncak absorpsi terjadi pada panjang gelombang disekitar 508,7- 554,6 nm dengan nilai absorbansi disekitar 0,0003-0,0121 A.u. selanjutnya pengukuran dilakukan pada panjang gelombang tersebut.

Hasil yang diperoleh pada karakterisasi menggunakan spektrometer UV-Vis adalah nilai absorbansi larutan, sehingga diperlukan grafik larutan standar untuk memperoleh konsentrasi larutan. Nilai absorbansi untuk setiap konsentrasi dapat digambarkan pada grafik yang ditunjukkan pada Gambar 4 untuk massa arang aktif 0,5 gram dan Gambar 6 untuk massa arang aktif 0,8 gram.

Berdasarkan semua persamaan linier pada Gambar 4 dapat ditentukan nilai konsentrasi (x) larutan $\mathrm{Pb}$ dengan nilai y sebagai absorbansi larutan. Konsentrasi larutan $\mathrm{Pb}$ asetat setelah dicampurkan dengan arang aktif EG untuk semua sampel terdapat pada Tabel 2 dan 3. 


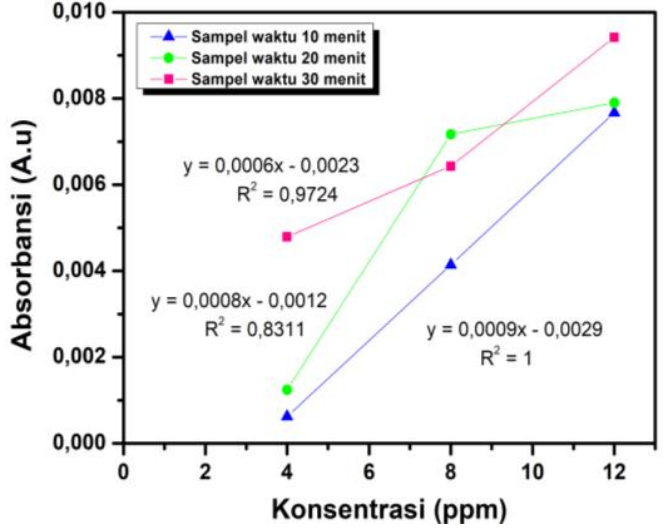

(a)

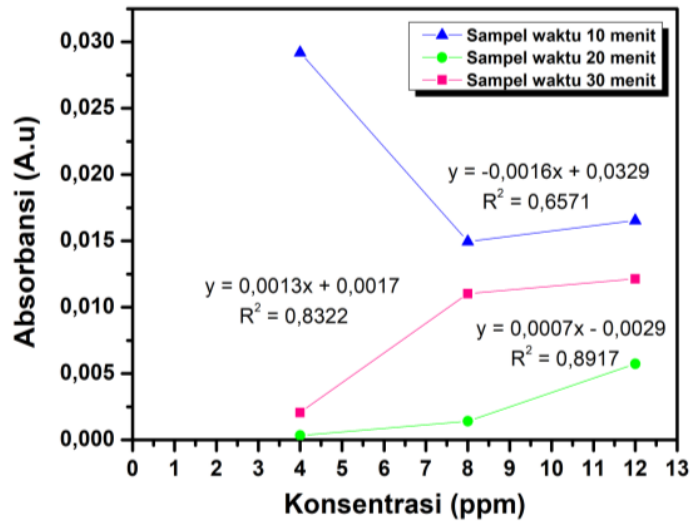

(b)

Gambar 4. Grafik absorbansi maksmimum untuk arang aktif (a) 0,5 gram dan (b) 0,8 gram

Tabel 2. Konsentrasi $\mathrm{Pb}$ asetat setelah dicampurkan dengan arang aktif EG sebesar 0,5 gram

\begin{tabular}{cccccc}
\hline $\begin{array}{c}\text { Massa } \\
(\text { gram })\end{array}$ & $\begin{array}{c}\text { Waktu } \\
(\text { menit })\end{array}$ & $\begin{array}{c}\text { Konsentrasi awal } \\
\text { Pb asetat } \\
(\mathrm{ppm})\end{array}$ & $\begin{array}{c}\text { Konsentrasi akhir } \\
\text { Pb asetat } \\
(\mathrm{ppm})\end{array}$ & $\begin{array}{c}\text { Daya serap } \\
(\mathrm{mg} / \mathrm{g})\end{array}$ & $\begin{array}{c}\text { Efisiensi } \\
(\%)\end{array}$ \\
\hline \multirow{2}{*}{10} & 4 & 3,91 & 0,0035 & 2,22 \\
& 8 & 7,82 & 0,0071 & 2,22 \\
& \multirow{2}{*}{0} & 4 & 11,74 & 0,0102 & 2,13 \\
0,5 & 8 & 3,05 & 0,038 & 23,75 \\
& \multirow{2}{*}{20} & 12 & 10,46 & $-0,0985$ & $-30,78$ \\
& \multirow{2}{*}{30} & 4 & 11,37 & 0,025 & 5,21 \\
& & 4 & 4,15 & $-0,006$ & $-3,75$ \\
& 12 & 6,88 & 0,0446 & 13,96 \\
& & 11,86 & 0,0053 & 1,11 \\
\hline
\end{tabular}

Tabel 3. Konsentrasi $\mathrm{Pb}$ asetat setelah dicampurkan dengan arang aktif EG sebesar 0,8 gram

\begin{tabular}{cccccc}
\hline $\begin{array}{c}\text { Massa } \\
(\text { gram })\end{array}$ & $\begin{array}{c}\text { Waktu } \\
(\text { menit })\end{array}$ & $\begin{array}{c}\text { Konsentrasi awal } \\
\text { Pb asetat } \\
(\mathrm{ppm})\end{array}$ & $\begin{array}{c}\text { Konsentrasi akhir } \\
\text { Pb asetat } \\
(\mathrm{ppm})\end{array}$ & $\begin{array}{c}\text { Daya serap } \\
(\mathrm{mg} / \mathrm{g})\end{array}$ & $\begin{array}{c}\text { Efisiensi } \\
(\%)\end{array}$ \\
\hline \multirow{2}{*}{10} & 4 & 2,31 & 0,0422 & 42,19 \\
& 8 & 11,22 & $-0,0805$ & $-40,23$ \\
& \multirow{2}{*}{20} & 4 & 10,22 & 0,0444 & 14,79 \\
0,8 & 8 & 4,63 & $-0,0157$ & $-15,71$ \\
& & 12 & 6,16 & 0,0461 & 23,03 \\
& \multirow{2}{*}{30} & 4 & 12,34 & $-0,0086$ & $-2,86$ \\
& & 8 & 2,89 & 0,0277 & 27,69 \\
& 12 & 9,79 & $-0,0449$ & $-22,41$ \\
& & 10,65 & 0,0336 & 11,22 \\
\hline
\end{tabular}

Tabel 2 menunjukkan konsentrasi larutan $\mathrm{Pb}$ asetat setelah dilakukan pengujian oleh arang aktif eceng gondok dengan massa 0,5 gram dalam 20 ml larutan $\mathrm{Pb}$ asetat untuk setiap variasi waktu kontak arang aktif dengan larutan $\mathrm{Pb}$ asetat dan variasi konsentrasi larutan $\mathrm{Pb}$ asetat. Pada arang aktif eceng gondok dengan massa 0,5 gram yang memiliki efisiensi terbaik sebesar 23,75\% terdapat pada konsentrasi larutan $\mathrm{Pb}$ asetat 4 ppm dengan waktu kontak antara arang aktif dengan laruitan $\mathrm{Pb}$ 
asetat selama 20 menit serta daya serap terhadap larutan $\mathrm{Pb}$ asetat sebesar 0,038 $\mathrm{mg} / \mathrm{g}$.

Tabel 3 menunjukkan konsentrasi larutan $\mathrm{Pb}$ asetat setelah dilakukan pengujian oleh arang aktif eceng gondok dengan massa 0,8 gram dalam 20 ml larutan $\mathrm{Pb}$ asetat untuk setiap variasi waktu kontak arang aktif dengan larutan $\mathrm{Pb}$ asetat dan variasi konsentrasi larutan $\mathrm{Pb}$ asetat. Pada arang aktif eceng gondok dengan massa 0,8 gram yang memiliki efisiensi terbaik sebesar 27,69\% terdapat pada konsentrasi larutan $\mathrm{Pb}$ asetat 4 ppm dengan waktu kontak antara arang aktif dengan laruitan $\mathrm{Pb}$ asetat selama 30 menit serta daya serap terhadap larutan $\mathrm{Pb}$ asetat sebesar 0,027 $\mathrm{mg} / \mathrm{g}$. Dalam data diatas terdapat larutan $\mathrm{Pb}$ asetat dengan kosentrasi akhir yang lebih tinggi dari konsentrasi awal sehingga mengakibatkan efisiensi bernilai negatif. Hal ini dikarenakan kapasitas permukaan arang aktif (adsorben) sudah jenuh dengan adsorbat sehingga adsorbat yang belum teradsorpsi berdifusi keluar pori dan kembali ke arus fluida [5]. EfIsiensi negatif rata-rata terjadi pada waktu 30 menit yang menjelaskan bahwa waktu optimum arang aktif (adsorben) dapat menyerap larutan $\mathrm{Pb}$ asetat (adsorbat) berada pada waktu 20 menit karena saat waktu 30 menit sudah tidak terjadi adsorpsi karena sudah dalam keadaan jenuh.

\section{Kesimpulan}

Dari hasil dan pembahasan dapat diambil kesimpul bahwa temperature karbonisasi $400^{\circ} \mathrm{C}$ selama 1 jam menghasilkan karbon terikat sebesar 37,79\%. Hasil aktivasi dengan $\mathrm{ZnCl}_{2} \quad 30 \%$ menghasilkan total volume pori sebesar $0,055 \mathrm{cc} / \mathrm{g}$ luas permukaan spesifik sebesar 104,32 $\mathrm{m}^{2} / \mathrm{g}$. Pengaruh arang aktif sebagai adsroben terhadap limbah $\mathrm{Pb}$ asetat secara keseluruhan konsentrasi larutan $\mathrm{Pb}$ asetat mengalami penurunan. Penurunan terbesar diperoleh untuk massa arang aktif 0,5 gram sebesar $23,75 \%$ pada konsentrasi larutan $\mathrm{Pb}$ asetat 4 ppm dengan waktu selama 20 menit, dan penurunan terbesar diperoleh untuk massa arang aktif 0,8 gram sebesar 27,69 \% pada konsentrasi larutan $\mathrm{Pb}$ asetat 4 ppm dengan waktu selama 30 menit. Hasil yang diperoleh pada penelitian ini menunjukkan bahwa waktu kontak dan banyaknya massa arang aktif berpengaruh terhadap penurunan konsentrasi larutan $\mathrm{Pb}$ asetat, dimana semakin lama waktu kontak dan semakin banyak arang aktif yang digunakan sebagai adsorben maka semakin besar penururnan konsentrasi larutan $\mathrm{Pb}$ asetat artinya semakin besar persentase penyerapan pada larutan $\mathrm{Pb}$ asetat.

\section{DaftarPustaka}

1. E. R. Apipah. Sifat Listrik Arang Aktif Dari Tumbuhan Eceng Gondok (Eichornia crassipes) Sebagai Bahan Semikonduktor. Tesis, (2016) 1.

2. J. Rorong \& E. Suryanto. Analisis Fitokimia Eceng Gondok (Eichhornia crassipes) Dan Efeknya Sebagai Agen Photoreduksi Fe ${ }^{3+}$. Chem. Prog., 3 (1) (2010) 33.

3. C. Gunnarsson \& C.M. Petersen. Water Hyacinth as a Resources Agriculture and Energy Production: A Literature Review. Waste Management, 27 (2007) 117-129. 
4. A. L. Prabowo. Pembuatan Karbon Aktif Dari Tongkol Jagung Serta Aplikasinya Untuk Adsorpsi $\mathrm{Cu}, \mathrm{Pb}$, Dan Amonia. Depok: Universitas Indonesia (2009).

5. C. Suprianofa. Pembuatan Karbon Aktif Dari Kulit Durian Sebagai Adsorben Zat Warna Dari Limbah Cair Tenun Songket Dengan Aktivator KOH. (2016, Agustus 4) Retrieved from Eprints: http://eprints.polsri.ac.id. 